\title{
Analytical tools for ensuring economic security in the conditions of global competitiveness: theoretical aspect
}

\author{
Nina Avanesova ${ }^{1}$, Olena Kirdina ${ }^{2}$, Irina Volovelska ${ }^{3}, V$ Valentina Maslova ${ }^{3}$, and \\ Yuliya Utkina ${ }^{31}$ \\ ${ }^{1}$ Kharkov National University of Civil Engineering and Architecture, Department of Management \\ and Public Administration, 61002 Sumska st. 40, Kharkiv, Ukraine \\ ${ }^{2}$ Ukrainian State University of Railway Transport, Department of Accounting and Audit, 61050 \\ Feierbakh sq. 7, Kharkiv, Ukraine \\ ${ }^{3}$ Ukrainian State University of Railway Transport, Department of Economics and Management of \\ Industrial and Commercial Business, 61050 Feuerbakh sq. 7, Kharkiv, Ukraine
}

\begin{abstract}
Global competitiveness, based on the international division of labor, the use of factors of production and the country's place in the world market ensures the ability of the state to participate in the competition and the full use of its own competitive advantages. Globalization processes have negative consequences for functioning of national economies, which actualizes the problem of ensuring the economic security of countries. The economic security of the state is the criterion of the effectiveness of the state economic policy and characterizes the overall level of the country's economy; the presence and level of threats to the state, society or person; the effectiveness of state regulation of the economy; the full implementation of the functions of the state. At the same time, its analytical tools are based on the most important parameters of the state of the economic system, its stability and mobility: GDP growth, the level and quality of life of the majority of the population, inflation, unemployment, the structure of the economy, the property stratification of the population, criminalization and shadowing of the economy, the state of the technical and technological base of the economy, spending on research, import dependence, economic openness, internal and external debt.
\end{abstract}

\section{Introduction}

The growing trends of globalization and integration of the world economy make it necessary to ensure competitiveness in the global dimension. Now, according to the world economic forum, which is held annually in Davos (Switzerland), in the world ranking on the global competitiveness Index 2017-2018, Ukraine occupies the 81st position among 134 countries participating in the evaluation. Switzerland traditionally tops the rating, and up to 10 most competitive economies included the USA, Singapore, the Netherlands, Germany, Hong Kong, Sweden, the UK, Japan and Finland [1].

Global competitiveness means the ability to perceive new knowledge and trends of global development, adapt to them and adapt them to themselves in such a way as to be included in global processes without destroying the internal integrity and preserving their national and cultural identity, as well as to compete and win a worthy place in the system of international territorial division of labor [2]. It is provided through the formation of competitive advantages in the areas of social structure and the structure of the economy, regional accessibility and culture, innovation, environment, skills of the workforce. Within

\footnotetext{
${ }^{1}$ Corresponding author: yuliyautkina@ukr.net
} 
the limits of actual competitiveness, GDP growth is observed by increasing the efficiency of labor and employment of the population under the influence of attracting foreign investment, the development of small and medium-sized enterprises, research and technological development, infrastructure and human capital, intellectual and social capital. At the level of global competitiveness of the national economy, GDP growth correlates with the quality of life of the population, providing a stable competitive position and the well-being of the population in the long term.

It is the global competitiveness based on the international division of labor, the use of factors of production and the country's place in the world market that ensure the ability of the state to participate in the competition and the full use of its own competitive advantages. At the same time, globalization processes have negative consequences for the functioning of national economies, which actualizes the problem of ensuring the economic security of countries.

\section{Main part}

Global competitiveness is the potential or realized ability of a subject of international competition to operate in the global economic space, which is based on the use of global competitive advantages and aimed at achieving the goals of its international business.

With the increasing globalization of competition, the importance of the development and implementation of global competitiveness strategies in the practice of world market players is also increasing. A global approach to the formation of international competitiveness strategies is now defined as an effective way that provides economies of scale, assimilation and response to international market demand, and an effective combination of resources - capital, labor, raw materials and technology - worldwide.

Most aspects of global competitiveness strategies are based on the formation of a certain type of competitive advantages, which are determined by the characteristics of the industry, sources and factors of competition in it. At the same time, global competitiveness strategies are based on a fundamentally different paradigm of competitive advantage formation, which does not recognize borders between countries. This "panoramic approach" to the management of the processes of formation and realization of global advantages in a much more complex geo-economic space requires the use of traditional principles and methods of management, and a new version of it - the so-called goal of management, or metamanagement.

For industries and industries of primary sectors of the economy, the international economic activity of which is based on the exploitation of mainly resource-factor advantages, non-economic factors of global competitiveness are created, first of all, by the purposeful policy of the governments of the countries on the basis of:

- control of the world's raw materials and diversification of sources of reliable supply;

- control of global transport communications;

- influence on political and economic systems of the countries-suppliers of raw materials on the world markets;

- introduction of environmental, social and other norms and standards of safe business in basic industries.

The advantages that are created by maintaining the stability of global commodity markets and enhancing the security of global business strengthen the competitive position of transnational structures.

Global competitiveness is not a problem only for the primary sectors of the economy. Active formation of global advantages is manifested, first of all, in industries and industries that exploit resource and technological and innovative advantages. 
Governmental assistance in the formation of global advantages of these industries is provided primarily through:

- formation of innovative infrastructure of the economy;

- facilitating the flow of highly skilled labour from other countries of the world;

- creation of a global business information system;

- ensuring the secrecy of technological innovations and their uncontrolled spread;

- protection of copyright and intellectual property through international organizations.

Innovation and technological advantages are the main means of entering the strategic flow of modern international economic exchange. Generation of a qualitatively new state of technology - "metatechnology" - creates a monopolistically advantageous global competitive position of the developed countries of the West. Among the non-Western countries, only ten of them - China, Japan, India, Brazil, Turkey, Poland and some others are considered today to be integrated into the global economy. Among them there is not a single country of the post-Soviet space, including Ukraine, because a country with a dominant development of primary sectors of the economy cannot enter the system of the global economy [4-5].

In the context of non-proliferation of destructive reforms of the industrial sector of the economy, the dominance of imports, the uncertainty of the political situation in the country, as well as under the influence of military aggression in Eastern Ukraine and the annexation of Crimea, the state in recent years has lost more than $20 \%$ of its economic potential [3], which had significant negative consequences:

- destruction of the productive capacity of the country and the breach of cooperative ties between enterprises of individual regions;

- narrowing of export potential;

- reducing the investment attractiveness of the economy and curtailing investment activity;

- reduction of the internal resource base of the fuel and energy complex;

- reducing the competitiveness of the national transport system and the loss of transit capacity;

- growth of social tension and protest moods in society [6]

In numerous researches of scientists it is defined that economic security characterizes a state of national economy at which economic stability to internal and external threats remains and needs in system "person-society-state" are satisfied. Given the ability of economic security to ensure and maintain a stable competitive position of the national economy in the world economic system, to self-development and self-improvement, we note that economic security is not only an indicator of the internal state of the national economy, but also quite fully characterizes its external relations and interaction with the external environment.

Integration processes of recent times put before the economy of Ukraine a number of issues to ensure a sufficient level of foreign economic security of the state, because it is foreign economic security is the "guarantor" of full participation in the international division of labour, the system of world economic relations and the system of protection and countering global challenges and threats. During the integration of the state into the system of world economic relations, it faces the problem of contradiction between the need, on the one hand, to integrate into the world economy, and on the other - to ensure the harmonious development of the national economy, the protection of national economic interests, the domestic market and domestic producers. Given this, it should be recognized extremely ambiguous impact of globalization on the state of socio-economic security along the hierarchy - from the level of the state to the level of the citizen [7-8].

At the same time, it should be noted the indisputable role of foreign economic security in ensuring the global competitiveness of the country, which is part of the world economic space. One of the fundamental processes of market transformation of the national industrial 
complex of Ukraine is its integration into the world economic relations, as a result of which it gradually becomes part of the world industrial system. The formation of such a system is the result of the process of globalization of the economic space, characterized by the growing interdependence of national economies, increasing integrity and unity of the world economic system on the basis of increased openness of national markets and deepening of the international division and integration of labour [9].

In the context of sustainable post-industrial development of society and state institutions, when the state is able to confront the emerging internal and external threats to stability in all areas of economic security in the global competitive environment is a really achievable process. At the same time, in our opinion, it is expedient to define and establish security standards, the violation of which leads to destabilization in the economy or social sphere, and their thresholds. At the same time, the deviation of the actual levels of indicators from the threshold values to determine the system of priorities of economic security of the state in the global dimension.

According to [10] the main indicators and threshold values of indicators of macroeconomic security of Ukraine are as follows:

- the level of "shadowing" the economy - no more than 30\% of GDP;

- the ratio of GDP to the average value in the EU - at least $75 \%$;

- ratio of GDP per capita to the average value in the EU - at least 50\%;

- the ratio of GDP per person to the global average - not less than $100 \%$;

- changes in inventories should be in the range of -1.5 to $+1.5 \%$ of GDP;

- the ratio of the balance of payments of Ukraine to GDP should be in the range from -1 to $+1 \%$;

- share of available income of non-financial corporations in gross available income-not less than $14-15 \%$;

- the share of the sector of public administration in the available income - no more than $20 \%$.

\section{Conclusion}

Globalization processes taking place in modern society are reflected in the change of functional components at various levels of economic security. The above-mentioned components change from ensuring the primary needs of the citizen through the financial independence of enterprises to improving the efficiency of the object of study at the industry level. With the further consolidation of the scope of application of the concept of economic security to the regional and national level, the functional components used to characterize the primary needs, to which the financial, technological, innovative and energy parameters are added, come to the first place. At the same time, only international competitiveness, a set of international conditions for coexistence and inter-state relations are taken into account at the global level. Globalization trends in the economy directly affect economic security and are aimed primarily at meeting the needs and economic interests of the individual or household. Thus, an attempt at the state, international and global level to bring the dependence of economic security on the functional components of the higher order, facilitate the task only for the highest state functionaries, narrowing and simplifying the strategic goals that they should achieve.

Economic security of the state is the criterion of the effectiveness of the state economic policy and characterizes the overall level of the country's economy; the presence and level of threats to the state, society or person; the effectiveness of state regulation of the economy; the full implementation of the functions of the state. At the same time, its analytical tools are based on the most important parameters of the state of the economic system, its stability and mobility: GDP growth, the level and quality of life of the majority 
of the population, inflation, unemployment, the structure of the economy, the property stratification of the population, criminalization and shadowing of the economy, the state of the technical and technological base of the economy, spending on research, import dependence, economic openness, internal and external debt.

\section{References}

1. Pozycija Ukrainy $v$ rejtynghu krajin svitu za Indeksom ghlobaljnoji konkurentospromozhnosti 2017-2018. URL: http://edclub.com.ua/analityka/pozyciya-ukrayiny-v-reytyngu-krayin-svitu-zaindeksom-globalnoyi-konkurentospromozhnosti-2

2. N.Ya. Kalyuzhnova. Konkurentosposobnost rossiyskikh regionov $v$ usloviyakh globalizatsii, TEIS, 526 (2003)

3. O.V. Sobkevich. Собкевич O.B. Ocinka vtrat ta mekhanizm vidbudovy realjnogho sektoru ekonomiky skhodu Ukrajiny. [URL: http://www.niss.gov.ua/articles/1832/

4. T.A. Kocko T.A. Ekonomichna bezpeka terytorialjno-vyrobnychykh kompleksiv: energhetyka, ekologhija, informacijni tekhnologhiji, MP Lesja, 256 (2015)

5. O.M. Lyashenko. Economy. Management. Business. 17(II), 179-187 (2007)

6. Metodyka rozrakhunku rivnja ekonomichnoji bezpeky Ukrajiny. URL: http://www.kmu.gov.ua/control/ru

7. G.V. Kozachenko, V.P. Ponomapev, O.M. Lyashenko. Ekonomichna bezpeka pidpryyemstva: sutnist ta mekhanizm zabezpechennya, Libra, 280 (2003)

8. N. Avanesova, I. Volovelska, V. Maslova, T. Sukhorukova, Yu. Utkina. Inetrnational Journal of Engineering \& Technology. 7(4.3). 393-397 (2018)

9. V.L. Dykan. The bulletin of transport and industry economics. 34, 141-147 (2011)

10. A.V. Tolstova, K.V. Khomenko. The bulletin of transport and industry economics. 63, 187-195 (2018) 